RESEARCH PAPER

\title{
Changes in hospitality workers' exposure to secondhand smoke following the implementation of New York's smoke- free law
}

\author{
M C Farrelly, J M Nonnemaker, R Chou, A Hyland, K K Peterson, U E Bauer
}

Tobacco Control 2005;14:236-241. doi: 10.1136/tc.2004.008839

See end of article for authors' affiliations

Correspondence to: Correspondence to:
Dr Matthew C Farrelly, RTI International, 3040

Cornwallis Road, Research Triangle Park, NC 27709, USA; mcł@rti.org

Received 21 May 2004 Accepted 23 March 2005
Objective: To assess the impact on hospitality workers' exposure to secondhand smoke of New York's smoke-free law that prohibits smoking in all places of employment, including restaurants, bars, and bowling facilities.

Design: Pre-post longitudinal follow up design.

Settings: Restaurants, bars, and bowling facilities in New York State.

Subjects: At baseline, 104 non-smoking workers in restaurants, bars, and bowling facilities were recruited with newspaper ads, flyers, and radio announcements. Of these, 68 completed a telephone survey and provided at least one saliva cotinine specimen at baseline. At three, six, and 12 month follow up studies, 47,38 , and 32 workers from the baseline sample of 68 completed a telephone survey and provided at least one saliva cotinine specimen.

Intervention: The smoke-free law went into effect 24 July 2003.

Main outcome measures: Self reported sensory and respiratory symptoms and exposure to secondhand smoke; self administered saliva cotinine specimens. Analyses were limited to subjects in all four study periods who completed a telephone survey and provided at least one saliva cotinine specimen.

Results: All analyses were limited to participants who completed both an interview and a saliva specimen for all waves of data collection $(\mathrm{n}=30$ ) and who had cotinine concentrations $\leqslant 15 \mathrm{ng} / \mathrm{ml}(\mathrm{n}=24)$. Hours of exposure to secondhand smoke in hospitality jobs decreased from 12.1 hours $(95 \%$ confidence interval (Cl) 8.0 to 16.3 hours) to 0.2 hours $(95 \% \mathrm{Cl}-0.1$ to 0.5 hours) ( $p<0.01$ ) and saliva cotinine concentration decreased from $3.6 \mathrm{ng} / \mathrm{ml}(95 \% \mathrm{Cl} 2.6$ to $4.7 \mathrm{ng} / \mathrm{ml})$ to $0.8 \mathrm{ng} / \mathrm{ml}(95 \% \mathrm{Cl} 0.4$ to $1.2 \mathrm{ng} / \mathrm{ml})$ ( $p<0.01$ ) from baseline to the 12 month follow up. The prevalence of workers reporting sensory symptoms declined from $88 \%$ (95\% Cl $66 \%$ to $96 \%$ ) to $38 \%$ (95\% Cl 20\% to 59\%) ( $p<0.01$ ); there was no change in the overall prevalence of upper respiratory symptoms $(p<0.16)$.

Conclusion: New York's smoke-free law had its intended effect of protecting hospitality workers from exposure to secondhand smoke within three months of implementation. One year after implementation, the results suggest continued compliance with the law.
$\mathrm{T}$ here is a well established causal link between exposure to secondhand smoke and increased morbidity and mortality. Epidemiological and other studies have demonstrated that secondhand smoke exposure increases the risk of lung cancer, ${ }^{1}$ cardiovascular disease, ${ }^{2}$ stroke, ${ }^{3}$ and asthma. ${ }^{4}$

State and local laws restricting or prohibiting smoking in public places (such as public transportation, retail stores, private workplaces, restaurants, and bars) have increased steadily since the 1986 Surgeon General report on the health effects of secondhand smoke. ${ }^{5}$ With only a few exceptions, however, state laws have not prohibited smoking in private workplaces, restaurants, and bars. California banned smoking in private workplaces in 1995 and restaurants and bars in 1998. Connecticut, Delaware, and Maine have enacted similar restrictions that include restaurants and bars.

On 26 March 2003, the New York State legislature passed and the governor signed into law amendments to the statewide Clean Indoor Air Act (Chapter 13 of the Laws of 2003) that prohibit smoking in all places of employment, including restaurants, bars, and bingo and bowling facilities. The law limits exemptions to retail tobacco businesses, membership associations where no compensation is provided for on-premises services, hotel rooms rented by one or more guests, existing cigar bars, and outdoor seating areas of bars. The law went into effect on 24 July 2003.
Research has shown that smoke-free policies in restaurants and bars reduce exposure to secondhand smoke ${ }^{6}$ and lead to improved respiratory and sensory symptoms among restaurant and bar workers. ${ }^{78}$ This study was designed to assess the impact of the amended state law on tobacco smoke exposure among a cohort of non-smoking hospitality workers in areas of New York not covered by local smoke-free workplace laws. Baseline data were collected before implementation of the state law, with follow ups occurring among the same study participants three, six, and 12 months after the law went into effect.

\section{METHODS}

To assess the impact of New York's law on exposure to secondhand smoke among current employees of restaurants, bars, or bowling facilities, we conducted a brief telephone survey of and obtained saliva specimens from a cohort of such workers before implementation of the law and three, six, and 12 months after the law went into effect. The brief survey assessed self reported exposure to secondhand smoke in the workplace and other settings, respiratory symptoms in the past four weeks using five questions from the International Union Against Tuberculosis and Lung Disease Bronchial Symptoms Questionnaire (wheeze, shortness of breath, morning cough, cough during the remainder of the 
day or night, phlegm), sensory irritation in the past four weeks (eye, nose, throat), and attitudes toward exposure to secondhand smoke.

Once study eligibility was determined during a screening interview, interviewers inquired about the participants' work schedule to arrange for the collection of two separate postwork shift saliva specimens and a post-work shift interview. Participants were instructed to collect both saliva samples immediately after a shift at work. Interviews were scheduled to take place after the saliva samples had been received at the lab. Participants were sent four sample kits (vials and cotton swabs), a consent form, a postage paid express mail return package, and instructions for collecting the samples. The telephone survey was scheduled to occur within four days of the first sample collection. We offered participants $\$ 40$ for completing both the baseline sample collection and survey. Baseline data collection began 30 June and was completed before 24 July 2003. Follow up data collection periods for the three, six, and 12 month follow up studies were 15 October to 19 November 2003; 20 February to 23 March 2004; and 1 July to 31 July 2004.

To be eligible for the study, participants had to be 18 years of age or older; non-tobacco users; non-nicotine replacement therapy users; and current employees of restaurants, bars, or bowling facilities in New York that allowed smoking at the time of the baseline survey. Eligibility was determined with a brief series of screening questions administered by telephone.

Participants in the baseline study who continued to meet the eligibility requirements were included in the follow up studies. Non-smokers were eligible for both a telephone interview and a saliva cotinine test. Those who reported that they now smoke, even if only occasionally, were eligible to complete the interview only.

Study participants were recruited through newspaper ads, flyers, and radio announcements. We also used a snowball sampling technique: people who called in responses to these solicitations were asked to refer others to the study. Newspaper ads were placed in six local newspapers (Albany Times-Union, Syracuse Post-Standard, [Buffalo area] Metro Community News, Rochester Democrat-Chronicle, Poughkeepsie Journal, and the Binghamton Press \& Sun-Bulletin). Flyers were distributed near restaurants, bars, and bowling facilities in 15 cities in the eligible area. Radio ads were placed in two primary areas. The ads in Buffalo and Niagara Falls ran for an average of three days, once an hour on six different local stations. These stations also had secondary markets in Rochester, Jamestown, Olean, Bradford, and/or Hamilton. Ads were also placed with four local stations in the Syracuse area.

Potential participants were asked to call a toll-free telephone number at RTI. Project staff followed a telephone script to confirm eligibility, describe the study and the procedures, collect contact information, and invite the caller to participate.

Approximately 3, 6, and 12 months after the baseline survey, each participant was sent a letter inviting him or her to participate in the follow up study. Data collection followed the same procedures as at baseline. Study staff called the participant a few days after the letters were sent. Participants who agreed to take part in this phase of the project were again screened for eligibility. Eligible non-smokers were sent two saliva sample kits, and an appointment was made for the telephone interview. Study participants who had started smoking since the baseline survey were asked only for an interview. Those who returned the samples received an additional \$20 as a token of appreciation for their time and effort.

All samples were tested for salivary cotinine in duplicate using an enzyme immunoassay (performed at Salimetrics
LLC, State College Pennsylvania). The validity of using enzyme immunoassays to measure cotinine has been demonstrated. ${ }^{9}$ The test used $50 \mu \mathrm{l}$ of saliva and had a lower limit of sensitivity of $3 \mathrm{ng} / \mathrm{ml}$ for the baseline through six month follow up studies and $0.1 \mathrm{ng} / \mathrm{ml}$ for the 12 month follow up study. Intra-assay precision was determined from 32 samples each of 0 , low $(5 \mathrm{ng} / \mathrm{ml})$, and high $(50 \mathrm{ng} / \mathrm{ml})$ cotinine concentrations with coefficients of variation determined to be $4.3,8.3$, and 4.5 for each of the respective cotinine values. Inter-assay precision, determined from the mean of average duplicates for 32 separate runs for each cotinine value, resulted in coefficients of variation of $6.6 \%$, $9.6 \%$, and $6.5 \%$ for each respective cotinine concentration. Method accuracy, determined by spike recovery and linearity, averaged $99.4 \%$ and $95.9 \%$, respectively. The lowest detectable saliva cotinine concentration at baseline, three, and six month follow up is $3 \mathrm{ng} / \mathrm{ml}$; those with undetectable concentrations of cotinine were set to $1.5 \mathrm{ng} / \mathrm{ml}$, halfway between 0 and $3 \mathrm{ng} / \mathrm{ml}$. For the 12 month follow up studies, the lowest detectable saliva cotinine concentration is $0.1 \mathrm{ng} / \mathrm{ml}$; undetectable concentrations were set to $0.05 \mathrm{ng} / \mathrm{ml}$, halfway between 0 and $0.1 \mathrm{ng} / \mathrm{ml}$.

\section{Statistical analyses}

For all waves of data collection, we constructed measures of secondhand smoke exposure for each study participant by calculating the mean cotinine concentration for the samples collected after each of the two work shifts. In general, two tests for each sample were administered unless an insufficient quantity remained after the first test to conduct a second test. The constructed mean cotinine concentration represents an average of all the sample test results for each valid sample. All participants had at least one valid sample to conduct the assay; however, some participants provided only

\section{Table 1 Participation by wave of data collection}

\begin{tabular}{|c|c|}
\hline & $\mathbf{n}$ \\
\hline \multicolumn{2}{|l|}{ Baseline } \\
\hline Successfully contacted & 116 \\
\hline Number eligible & 104 \\
\hline Number ineligible & 8 \\
\hline Refused & 4 \\
\hline Both interview and saliva sample & 68 \\
\hline Both interview and saliva sample $(<15 \mathrm{ng} / \mathrm{ml})$ & 53 \\
\hline Both interview and saliva sample (>15 ng/ml) & 15 \\
\hline \multicolumn{2}{|l|}{3 month follow up } \\
\hline Successfully contacted (out of 68 from baseline) & 65 \\
\hline Number eligible & 54 \\
\hline Number ineligible & 9 \\
\hline Refused & 2 \\
\hline Both interview and saliva sample & 47 \\
\hline Both interview and saliva sample ( $<15 \mathrm{ng} / \mathrm{ml})$ & 41 \\
\hline Both interview and saliva sample (>15 ng/ml) & 6 \\
\hline \multicolumn{2}{|l|}{6 month follow up } \\
\hline Successfully contacted (out of 68 from baseline) & 42 \\
\hline Number eligible & 38 \\
\hline Number ineligible & 4 \\
\hline Refused & 0 \\
\hline Both interview and saliva sample & 38 \\
\hline Both interview and saliva sample $(<15 \mathrm{ng} / \mathrm{ml})$ & 35 \\
\hline Both interview and saliva sample (>15 ng/ml) & 3 \\
\hline \multicolumn{2}{|l|}{12 month follow up } \\
\hline Successfully contacted (out of 68 from baseline) & 36 \\
\hline Number eligible & 35 \\
\hline Number ineligible & 1 \\
\hline Refused & 0 \\
\hline Both interview and saliva sample & 32 \\
\hline Both interview and saliva sample $(<15 \mathrm{ng} / \mathrm{ml})$ & 29 \\
\hline Both interview and saliva sample (>15 ng/ml) & 3 \\
\hline Completed all interviews and saliva samples & 30 \\
\hline Completed all interviews and saliva samples (<15 ng/ml) & 24 \\
\hline Completed all interviews and saliva samples (>15 ng/ml) & 6 \\
\hline
\end{tabular}


one sample per work shift and/or sample(s) for only one work shift. In addition, although participants were screened for their tobacco use and use of nicotine replacement therapies, some of the cotinine values suggested active smoking.

Although the maximum salivary cotinine concentration is not precisely known for a non-smoker exposed to heavy levels of secondhand smoke, such exposure typically produces salivary cotinine concentrations in the $1-10 \mathrm{ng} / \mathrm{ml}$ range. ${ }^{10}$ In a study of exposure to passive smoking among bar staff, Jarvis et al ${ }^{11}$ found the median salivary cotinine concentration to be $7.95 \mathrm{ng} / \mathrm{ml}$, but the range was $2.2-$ $31.3 \mathrm{ng} / \mathrm{ml}$. Pirkle et al $^{12}$ analysed NHANES III data and found for respondents aged 4 years or older that serum cotinine concentrations were bimodally distributed for tobacco users and non-users with little overlap. The separation occurred at cotinine concentrations of approximately $10.0-15.0 \mathrm{ng} / \mathrm{ml}$. This result has led some researchers to use $15 \mathrm{ng} / \mathrm{ml}$ as a cutpoint for distinguishing smokers from non-smokers. ${ }^{13}$ Etter et $a l^{14}$ found similar results for distinguishing smokers from non-smokers using saliva cotinine. They suggested $7.5 \mathrm{ng} / \mathrm{ml}$ as the cut-point but noted that a cut-point of $13 \mathrm{ng} / \mathrm{ml}$ provided "equally satisfactory results." In the current study, we excluded those with salivary cotinine values above $15 \mathrm{ng} /$ $\mathrm{ml}$ as likely smokers.

We also constructed a second measure of secondhand smoke exposure based on self reported hours of exposure. Participants were asked to report their hours exposed to secondhand smoke (that is, "Were you exposed to secondhand smoke...") within the past four days at work, home, car, and other locations. To measure total secondhand smoke exposure, we took the summation of all the hours a person reported exposure at any location and at all jobs. This measure was further subdivided into hospitality industry workplace exposure (based on job descriptions) and exposure in all other locations ( that is, non-hospitality jobs, home, car) to examine changes in both environments before and after the smoking prohibition went into effect.

To measure respiratory and sensory symptoms reported by study participants, we used questions adapted by Eisner $\mathrm{et} \mathrm{al}^{7}$ from the respiratory and sensory symptom questions from the International Union Against Tuberculosis and Lung Disease bronchial symptoms questionnaire. We created two dichotomous variables-whether study participants experienced any respiratory symptoms and whether they experienced any sensory symptoms-to measure the overall change in symptoms as a result of the law. In addition, we created two symptoms scales using the sum of respiratory or sensory symptoms to measure the average number of symptoms that participants reported before and after smoking was restricted.

To facilitate comparisons across all waves of data collection and to account for potential tobacco users, all analyses of cotinine and survey data are limited to those with cotinine values $\leqslant 15 \mathrm{ng} / \mathrm{ml}$ and those who participated in all four waves of data collection. Given the skewness of the cotinine data, we performed pre-post tests using Wilcoxon signed rank test (a non-parametric test) for non-normally distributed continuous variables and $t$ tests for normally distributed variables. We also plotted all cotinine values by wave of data collection to illustrate the distribution of values. For dichotomous variables (for example, any respiratory symptoms), we performed McNemar's $\chi^{2}$ tests.

We begin our analyses by presenting sociodemographic characteristics and approval for the Clean Indoor Air Act for participants of all four waves of data collection and participants in the baseline study who subsequently dropped out of the study. This comparison illustrates any potential bias introduced by attrition.

\section{RESULTS}

For the baseline study, 116 potential participants were screened for eligibility. One hundred and four were eligible, eight were ineligible, and four refused (table 1). Of the 104 eligible participants, $82.7 \%$ (86/104) completed the questionnaire and $76.0 \%$ (79/104) provided a saliva sample before 24 July. A total of 68 participants completed both the interview and a saliva sample (62.9\%) (68/108), 18 completed only the interview, and 11 provided only a saliva sample. Of these 68,47 (69\%), 38 (56\%), and 32 (47\%) completed both the interview and a saliva specimen at the three, six, and 12 month follow up studies, respectively (table 1).

Analysis of the survey data was limited to participants who completed baseline and follow up surveys and provided saliva specimens with cotinine values $\leqslant 15 \mathrm{ng} / \mathrm{ml}(\mathrm{n}=24)$. Six participants who participated in all four waves were excluded because they had cotinine values $>15 \mathrm{ng} / \mathrm{ml}$ in at least one

\begin{tabular}{|c|c|c|}
\hline & $\begin{array}{l}\text { Participants in all waves of } \\
\text { data collection }(n=24)\end{array}$ & $\begin{array}{l}\text { Baseline participants not in } \\
\text { subsequent waves }(n=29)\end{array}$ \\
\hline \multicolumn{3}{|l|}{ Age (years) } \\
\hline $18-26$ & $37.5 \%(20.3 \%$ to $58.5 \%)$ & $46.4 \%(28.7 \%$ to $65.1 \%)$ \\
\hline $27-35$ & $12.5 \%(3.93 \%$ to $33.3 \%)$ & $17.8 \%(7.4 \%$ to $37.2 \%)$ \\
\hline $36-45$ & $25 \%$ (11.4\% to $46.4 \%)$ & $17.9 \%(7.4 \%$ to $37.2 \%)$ \\
\hline $46+$ & $25 \%$ (11.4\% to $46.4 \%)$ & $17.9 \%(7.4 \%$ to $37.2 \%)$ \\
\hline \multicolumn{3}{|r|}{ 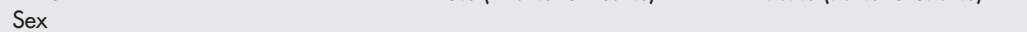 } \\
\hline Male & $29.2 \%$ (14.2\% to $50.6 \%)$ & $34.5 \%$ (19.3\% to $53.7 \%)$ \\
\hline \multicolumn{3}{|l|}{ Marital status } \\
\hline Married & $29.2 \%$ (14.2\% to $50.6 \%)$ & $24.1 \%(11.7 \%$ to $43.4 \%)$ \\
\hline Divorced & $8.3 \%(2.0 \%$ to $28.9 \%)$ & $10.3 \%$ (3.2\% to $28.4 \%$ ) \\
\hline Never married & $58.3 \%$ (37.7\% to $76.4 \%$ ) & $55.2 \%$ (36.6\% to $72.4 \%$ ) \\
\hline Other marital status & $4.2 \%(0.55 \%$ to $25.6 \%)$ & $10.4 \%$ (3.24\% to $28.4 \%$ ) \\
\hline \multicolumn{3}{|l|}{ Education } \\
\hline High school diploma & $50 \%(30.4 \%$ to $69.6 \%)$ & $38 \%$ (21.9\% to $57.0 \%)$ \\
\hline Technical/associate training & $37.5 \%$ (20.3\% to $58.5 \%)$ & $31 \%(16.6 \%$ to $50.4 \%)$ \\
\hline College degree & $12.5 \%(3.9 \%$ to $33.3 \%)$ & $31 \%(16.6 \%$ to $50.4 \%)$ \\
\hline \multicolumn{3}{|l|}{ Race } \\
\hline White & $95.8 \%(74.4 \%$ to $99.5 \%)$ & $93.1 \%$ (75.4\% to $98.4 \%)$ \\
\hline Other & $4.2 \%(0.55 \%$ to $25.6 \%)$ & $6.9 \%(1.7 \%$ to $24.6 \%)$ \\
\hline \multicolumn{3}{|l|}{ Baseline approval of CIAA } \\
\hline Approve & $72.7 \%$ (50.2\% to $87.6 \%)$ & $69.2 \%$ (48.7\% to $84.2 \%)$ \\
\hline
\end{tabular}


Table 3 Mean (95\% confidence interval) exposure to secondhand smoke for respondents by wave

\begin{tabular}{|c|c|c|c|c|c|c|}
\hline Exposure to secondhand smoke & Baseline & 3 month & 6 month & 12 month & p Value* & Trend $\ddagger$ \\
\hline $\begin{array}{l}\text { Proportion exposed to } \\
\text { secondhand smoke at hospitality } \\
\text { workplaces }\end{array}$ & $0.91(0.67$ to 0.98$)$ & $0.18(0.06$ to 0.42$)$ & $0.05(0.01$ to 0.30$)$ & 0.14 (0.04 to 0.37$)$ & $<0.001$ & $<0.001$ \\
\hline $\begin{array}{l}\text { Total hours exposed to } \\
\text { secondhand smoke }\end{array}$ & 14.5 (10.5 to 18.6$)$ & $2.9(-0.27$ to 6.04$)$ & $1.4(0.15$ to 2.63$)$ & $0.8(-0.01$ to 1.6$)$ & $<0.001 \dagger$ & $<0.001$ \\
\hline $\begin{array}{l}\text { Hours exposed to secondhand } \\
\text { smoke at hospitality workplaces }\end{array}$ & 12.1 (8.0 to 16.3$)$ & $1.6(-1.01$ to 4.23$)$ & $0.07(-0.07$ to 0.21$)$ & $0.2(-0.06$ to 0.47$)$ & $<0.001 \dagger$ & $<0.001$ \\
\hline $\begin{array}{l}\text { Hours exposed to secondhand } \\
\text { smoke at all other locations } \\
\text { (includes non-hospitality workplace } \\
\text { exposure) }\end{array}$ & $2.4(0.97$ to 3.83$)$ & $1.3(-0.17$ to 2.71$)$ & 1.3 (0.1 to 2.54$)$ & $0.6(-0.13$ to 1.31$)$ & $0.08+$ & 0.045 \\
\hline
\end{tabular}

Note: Two respondents had incomplete job descriptions at baseline and were excluded from the analyses.

* $p$ Values from baseline to 12 month follow up McNemar $\chi^{2}$ test unless otherwise noted.

tp Values from baseline to 12 month follow up Wilcoxon sign rank test.

$\ddagger \mathrm{p}$ Values from Cuzick non-parametric trend test across all waves.

wave of data collection. In addition, of these 24 , there were eight participants with cotinine values below the detectable limit at baseline, 12 at the three and six month follow up, and three at the 12 month follow up. Sociodemographic characteristics of the samples are presented in table 2 . Seventy three per cent of study participants approved of the Clean Indoor Air Act. In addition, there are no significant differences in sociodemographic characteristics between participants of all four waves of data collection and participants in the baseline study who subsequently dropped out of the study.

At baseline, participants were exposed to high levels of secondhand smoke exposure at their hospitality jobs, averaging 12.1 hours of exposure in the workplace over four days, with $91 \%$ of participants reporting exposure to secondhand smoke at any of their hospitality jobs (table 3). With low levels of exposure at non-hospitality workplaces and at all other locations (2.4 hours) at baseline, workplace exposure at hospitality jobs constituted the majority (83\%) of total exposure to secondhand smoke before the law went into effect.

Results of the follow up show a significant decline in workers' self reported exposure. The percentage of hospitality workers exposed to secondhand smoke declined by $85 \%$ $(\mathrm{p}<0.001)$, from $91 \%$ to $14 \%$ from baseline to the 12 month follow up, with most of the change occurring at the three month follow up. Total secondhand smoke exposure from all sources decreased from 14.5 hours to 0.8 hours from baseline to the 12 month follow up, representing a decline of $94 \%$ $(\mathrm{p}<0.001)$. The decrease in secondhand smoke exposure in hospitality workplaces represents an even greater change in exposure levels before and after the smoking prohibition went into effect. Secondhand smoke exposure in those workplaces declined by $98 \%(\mathrm{p}<0.001)$, from 12.1 to 0.2 hours.

Measured concentrations of cotinine in saliva samples of hospitality workers before and after the law went into effect are shown in table 4 and fig $\mathrm{l}$, using $15 \mathrm{ng} / \mathrm{ml}$ of cotinine as a cut-off for excluding potential tobacco users. Consistent with the declines in self reported exposure, cotinine values decreased significantly at the three month follow up. Cotinine concentrations averaged $3.6 \mathrm{ng} / \mathrm{ml}$ at baseline and dropped to $1.7 \mathrm{ng} / \mathrm{ml}$ and $0.8 \mathrm{ng} / \mathrm{ml}$ at the three and 12 month follow ups $(\mathrm{p}<0.001)$. Excluding participants with undetectable cotinine at baseline (eight out of the sample of 24 ) indicates a drop from 4.7 to 0.8 from baseline to the 12 month follow-up $(\mathrm{p}<0.001)$.

At baseline, $88 \%$ of respondents experienced any one of three sensory symptoms and reported an average of 1.6 sensory symptoms (table 5). By the 12 month follow up, the presence of one or more sensory symptoms decreased by $57 \%$ ( $\mathrm{p}<0.01$ ), from $88 \%$ to $38 \%$, and all individual symptoms declined significantly (table 5). Similarly, the total number of sensory symptoms experienced (symptom scale) declined by $69 \%(\mathrm{p}<0.01)$ from baseline (1.6) to the 12 month follow up (0.5).

Before the law went into effect, approximately $46 \%$ of respondents experienced any one of the following respiratory symptoms: wheezing/whistling in chest, shortness of breath, coughing in the morning, coughing during the day or at night, or bringing up any phlegm. This dropped by $37 \%$ to $29 \%$, but the decline was not significant. The most common respiratory symptom experienced was coughing during the day or at night, with $29 \%$ experiencing that symptom (table 5). The symptom scale shows that participants reported experiencing an average of 1.1 respiratory symptoms at baseline. By the 12 month follow up, there was a marginally significant change in coughing in the morningdropping by $62 \%$, from $21 \%$ to $8 \%(p=0.08)$.

\section{DISCUSSION}

In the USA, an increasing number of states have enacted laws to restrict smoking in restaurants and bars. In Europe, this issue is also garnering significant attention in the wake of Ireland's similar prohibition on smoking in pubs and most enclosed workplaces on 29 March 2004. ${ }^{15}$ Norway, Holland, and Italy have implemented similar restrictions since then with other countries considering similar bans. ${ }^{16}$ In fact,

Table 4 Mean (95\% confidence interval, n) cotinine concentrations

\begin{tabular}{|c|c|c|c|c|c|c|}
\hline Cotinine (ng/ml) & Baseline & 3 month & 6 month & 12-month & p Value* & Trendt \\
\hline Mean cotinine & 3.6 (2.56 to 4.67$) 24$ & 1.7 (1.44 to 2.0$) 24$ & $1.9(1.42$ to 2.3$) 24$ & $0.78(0.37$ to 1.19$) 24$ & $<0.001$ & $<0.001$ \\
\hline $\begin{array}{l}\text { Mean cotinine } \\
\text { (excludes respondents } \\
\text { with undetectable } \\
\text { cotinine at baseline) }\end{array}$ & $4.7(3.36$ to 5.98$) 16$ & $1.8(1.41$ to 2.25$) 16$ & $2.02(1.35$ to 2.69$) 16$ & $0.83(0.27$ to 1.4$) 16$ & $<0.001$ & $<0.001$ \\
\hline
\end{tabular}

* $p$ Values from baseline to 12 month follow up Wilcoxon sign rank test.

tp Values from Cuzick non-parametric trend test across all waves. 


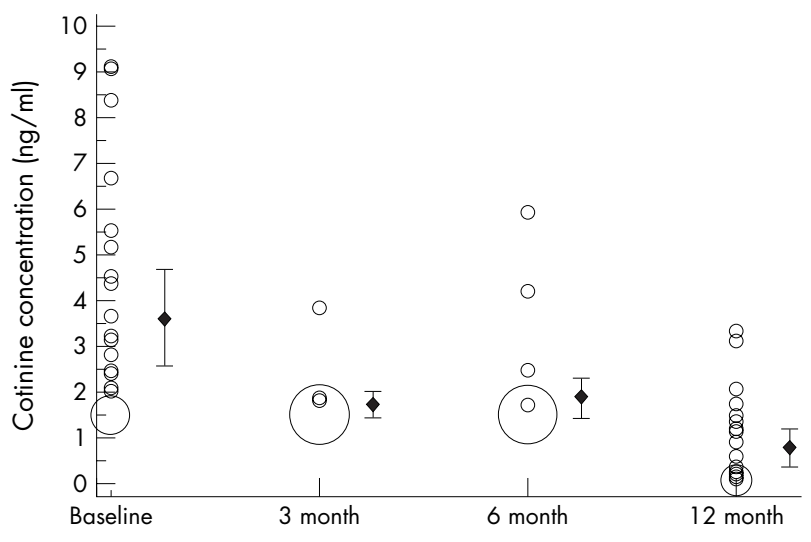

Note: Area of circles proportional to frequency of cotinine value for each wave

Figure 1 Mean, 95\% confidence intervals, and distribution of cotinine concentrations from baseline to 12 month follow up.

according to the European Union's Health Commissioner, David Byrne, smoking could be banned in restaurants, pubs, and cafes throughout Europe. ${ }^{17}$ The results of the current study show that such restrictions are an effective tool for protecting hospitality workers. Three months after implementation of a statewide law prohibiting smoking in restaurants, bars, and bowling facilities, workers in these establishments experienced substantial reductions in exposure to secondhand smoke measured by self reported exposure and saliva cotinine. In addition, exposure continued to decline through 12 months after implementation. As expected, secondhand smoke exposure at locations away from work, however, declined at a much slower rate. These results demonstrate that the law is having its intended effect
What this paper adds

One previous study demonstrated a decline in respiratory symptoms among hospitality workers following implementation of a statewide law restricting smoking in restaurants and bars.

This study shows that New York's statewide law restricting smoking in virtually all workplaces led to a significant decline in both saliva cotinine and self reported measures of exposure to secondhand smoke among non-smoking workers in restaurants, bars, and bowling facilities. These declines have persisted for at least a year, demonstrating continued compliance with the law.

of reducing employee exposure to a toxic substance in the workplace.

The study is not without its limitations. First, we were not able to find a sample frame from which we could recruit study participants or against which we could assess how representative our study sample is. Second, given the transient nature of this workforce, roughly half of the baseline sample was lost to follow up primarily due to changes in employment (that is, outside the affected industry) and moving out of state. However, comparing baseline statistics for those who participated across all waves to those who dropped out of the study after the baseline shows neither substantial differences in the composition of the sample (table 2) nor any significant differences at baseline across any of the outcomes (results available upon request), suggesting that no bias was introduced by attrition. Third, the cotinine test used in the baseline, three, and six month waves of the study was not as sensitive as it could have been. We addressed this limitation by performing a more sensitive test at the 12 month follow up study and by

Table 5 Mean (95\% confidence interval) self reported sensory symptoms for respondents of both waves

\begin{tabular}{|c|c|c|c|c|c|c|}
\hline & Baseline & 3 month & 6 month & 12 month & p Value* & Trend‡ \\
\hline \multicolumn{7}{|l|}{ Sensory symptoms } \\
\hline $\begin{array}{l}\text { Proportion with red or } \\
\text { irritated eyes }\end{array}$ & $0.67(0.44$ to 0.83$)$ & 0.21 (0.08 to 0.43$)$ & 0.12 (0.04 to 0.34$)$ & 0.25 (0.11 to 0.47$)$ & 0.004 & 0.002 \\
\hline $\begin{array}{l}\text { Proportion with runny nose, } \\
\text { sneezing, or nose irritation }\end{array}$ & $0.54(0.33$ to 0.74$)$ & $0.42(0.23$ to 0.63$)$ & $0.50(0.30$ to 0.70$)$ & 0.12 (0.04 to 0.34$)$ & 0.002 & 0.009 \\
\hline $\begin{array}{l}\text { Proportion with sore or } \\
\text { scratchy throat }\end{array}$ & $0.42(0.23$ to 0.63$)$ & $0.33(0.17$ to 0.56$)$ & $0.25(0.11$ to 0.47$)$ & 0.17 (0.06 to 0.39 ) & 0.058 & 0.046 \\
\hline $\begin{array}{l}\text { Proportion that experienced } \\
\text { any one of sensory symptoms }\end{array}$ & $0.88(0.66$ to 0.96$)$ & $0.67(0.44$ to 0.83$)$ & $0.54(0.33$ to 0.74$)$ & $0.38(0.20$ to 0.59$)$ & $<0.001$ & $<0.001$ \\
\hline $\begin{array}{l}\text { Sum of sensory symptoms } \\
\text { (sensory symptom scale) }\end{array}$ & 1.63 (1.22 to 2.03$)$ & 0.96 (0.57 to 1.34$)$ & $0.88(0.46$ to 1.29$)$ & 0.54 (0.19 to 0.89$)$ & $<0.001 \dagger$ & $<0.001$ \\
\hline \multicolumn{7}{|l|}{ Upper respiratory symptoms } \\
\hline $\begin{array}{l}\text { Proportion that experienced } \\
\text { wheezing or whistling in chest }\end{array}$ & 0.21 (0.08 to 0.43$)$ & $0.08(0.02$ to 0.30$)$ & $0.21(0.08$ to 0.43$)$ & 0.12 (0.04 to 0.34$)$ & 0.157 & 0.708 \\
\hline $\begin{array}{l}\text { Proportion that felt short of } \\
\text { breath }\end{array}$ & $0.17(0.06$ to 0.39$)$ & 0.12 (0.04 to 0.34$)$ & 0.17 (0.06 to 0.39$)$ & 0.08 (0.02 to 0.30$)$ & 0.157 & 0.507 \\
\hline $\begin{array}{l}\text { Proportion that experienced } \\
\text { coughing in morning }\end{array}$ & 0.21 (0.08 to 0.43$)$ & 0.12 (0.04 to 0.34$)$ & $0.08(0.02$ to 0.30$)$ & $0.08(0.02$ to 0.30$)$ & 0.083 & 0.17 \\
\hline $\begin{array}{l}\text { Proportion that experienced } \\
\text { coughing at all during the rest } \\
\text { of the day or at night }\end{array}$ & $0.29(0.14$ to 0.52$)$ & $0.25(0.11$ to 0.47$)$ & $0.38(0.20$ to 0.59$)$ & 0.21 (0.08 to 0.43$)$ & 0.414 & 0.762 \\
\hline $\begin{array}{l}\text { Proportion that experienced } \\
\text { bringing up any phlegm }\end{array}$ & 0.21 (0.08 to 0.43$)$ & $0.17(0.06$ to 0.39$)$ & $0.21(0.08$ to 0.43$)$ & 0.21 (0.08 to 0.43$)$ & No change & 0.909 \\
\hline $\begin{array}{l}\text { Proportion that experienced } \\
\text { any one of respiratory } \\
\text { symptoms }\end{array}$ & $0.46(0.26$ to 0.67$)$ & $0.46(0.26$ to 0.67$)$ & $0.50(0.30$ to 0.70$)$ & 0.29 (0.14 to 0.52$)$ & 0.157 & 0.313 \\
\hline $\begin{array}{l}\text { Sum of respiratory symptoms } \\
\text { (respiratory symptom scale) }\end{array}$ & $1.08(0.4$ to 1.76$)$ & $0.75(0.25$ to 1.25$)$ & $1.04(0.45$ to 1.63$)$ & 0.71 (0.13 to 1.29$)$ & $0.117 \dagger$ & 0.412 \\
\hline
\end{tabular}

* $p$ Values from baseline to 12 month follow up McNemar $\chi^{2}$ test unless otherwise noted.

tp Values from baseline to 12 month follow up Wilcoxon sign rank test.

łp Values from Cuzick non-parametric trend test across all waves. 
conducting a sub-analysis limiting the sample to those with detectable baseline cotinine values. This analysis shows a significant decline in cotinine values from baseline to the 12 month follow up. Finally, several of our measures (for example, respiratory symptoms) rely on participant self reports, which limits their sensitivity and accuracy.

These findings are corroborated by two recent observational studies in New York State that indicated that compliance with the law was high and that airborne concentrations of nicotine declined significantly. ${ }^{18}{ }^{19}$ Although neither these studies nor the current study indicate that hospitality workers are free of workplace exposure to secondhand smoke, the decline in exposure has been dramatic in a short period of time. Consistent with a previous study in California, ${ }^{7}$ the decline in secondhand smoke exposure found here was accompanied by a decline in the prevalence of sensory and respiratory symptoms.

In light of the health effects of chronic exposure to secondhand smoke, such as an increased risk of lung cancer, ${ }^{1}$ cardiovascular disease, ${ }^{2}$ and stroke, ${ }^{3}$ these findings have important implications for public health and the associated costs of smoking. Our findings indicate that approximately 258467 (233 309 full service restaurant, 18869 drinking industry, 6289 gambling industry) workers in the hospitality industry in New York State are now largely protected from exposure to secondhand smoke in the workplace. ${ }^{20}$ Based on the 1997 US Economic Census of workers in the full service restaurant, drinking industry, and gambling industry, an estimated 4131228 workers in the hospitality industry would enjoy similar protections if prohibitions were implemented throughout the USA.

\section{CONTRIBUTORS}

Matthew Farrelly and James Nonnemaker directed all analyses; contributed to the development of the survey instrument, study design, and data collection protocol; and participated in writing the manuscript.

Rosaleen Chou conducted all analyses, participated in writing the manuscript, and contributed to the development of the survey instrument.

Andrew Hyland and Ursula Bauer contributed to the development of the survey instrument, study design, and data collection protocol and participated in writing the manuscript.

Kristina Ahlen directed the field operations; contributed to the development of the survey instrument, study design, and data collection protocol; and participated in writing the manuscript.

The authors would like to thank Jeniffer Iriondo-Perez from RTI International for conducting the study's power analyses.

\section{Authors' affiliations}

M C Farrelly, J M Nonnemaker, R Chou, K K Peterson, RTI International, Research Triangle Park, North Carolina, USA
A Hyland, Roswell Park Cancer Institute, Buffalo, New York, USA U E Bauer, New York State Department of Health, City?, New York, USA Funding: This study was supported by the American Legacy Foundation and the New York State Department of Health.

Competing interests: none declared

\section{REFERENCES}

1 Hackshaw AK, Law MR, Wald NJ. The accumulated evidence on lung cancer and environmental tobacco smoke. BMJ 1997;315:980-8.

2 Law MR, Morris JK, Wald NJ. Environmental tobacco smoke exposure and ischaemic heart disease: an evaluation of the evidence. BMJ 1997;315:973-80.

3 Bonita R, Duncan J, Truelsen T, et al. Passive smoking as well as active smoking increases the risk of acute stroke. Tobacco Control 1999;8:156-60.

4 Mannino DM, Homa DM, Redd SC. Involuntary smoking and asthma severity in children: data from the Third National Health and Nutrition Examination Survey. Chest 2002; 122:409-15.

5 Chriqui JF, Frosh M, Brownson RC, et al. Application of a rating system to state clean indoor air laws (USA). Tobacco Control 2002;11:26-34.

6 Repace J. An air quality survey of respirable particles and particulate carcinogens in Delaware hospitality venues before and after a smoking ban. Bowie, Maryland: Repace Associates, 2003.

7 Eisner MD, Smith AK, Blanc PD. Bartenders' respiratory health after establishment of smoke-free bars and taverns. JAMA 1998;280:1909-14.

8 Wakefield M, Trotter L, Cameron M, et al. Association between exposure to workplace secondhand smoke and reported respiratory and sensory symptoms: cross-sectional study. J Occup Environ Med 2003;45:622-7.

9 Dhar P. Measuring tobacco smoke exposure: quantifying nicotine/cotinine concentration in biological samples by colorimetry, chromatography and immunoassay methods. J Pharm Biomed Anal 2004;35:155-68.

10 US Department of Health and Human Services. Second national report on human exposure to environmental chemicals. Atlanta, Georgia: National Center for Environmental Health, Centers for Disease Control and Prevention, United States Department of Health and Human Services, January, 2003.

11 Jarvis MJ, Foulds J, Feyerabend C. Exposure to passive smoking among bar staff. Br J Addict 1992;87:111-3.

12 Pirkle JL, Flegal KM, Bernert JT, et al. Exposure of the US population to environmental tobacco smoke: the Third National Health and Nutrition Examination Survey, 1988 to 1991. JAMA 1996;275:1233-40.

13 Caraballo RS, Giovino GA, Pechacek TF, et al. Factors associated with discrepancies between self-reports on cigarette smoking and measured serum cotinine levels among persons aged 17 years or older: Third National Health and Nutrition Examination Survey, 1988-1994. Am J Epidemiol 2001;153:807-14.

14 Etter JF, Vu Duc T, Perneger TV. Saliva cotinine levels in smokers and nonsmokers. Am J Epidemiol 2000;151:251-8.

15 Office of Tobacco Control. Smoke-free workplaces. http://www.otc.ie/ communication_smokefree.asp (Accessed Feb 20, 2005].

16 BBCNews. Smoking curbs: The Global Picture. http://news.bbc.co.uk/1/hi/ world/3758707.stm] [BBCNewsBan stubs out ltaly tobacco sales.http:// news.bbc.co.uk/1/hi/business/4195249.stm.

17 Condon D. Smoking may be banned in all EU pubs. Available from: http:// www. irishhealth.com/?level = 4\&id = 5253 (posted September 19, 2004).

18 Sciandra R. New law is clearing the air in bars and restaurants, two studies show. Press release. Center for a Tobacco Free New York, September 26, 2003.

19 Travers M, Cummings KM, Hyland A. Indoor air quality before and after the New York clean indoor air law in western New York hospitality venues, July to September 2003. Scottsdale, AZ: Presented at the 10th annual meeting of the Society for Research on Nicotine and Tobacco, 2004

20 New York State Department of Labor. Covered employment and wages for June 2003 (ES202). http://64.106.160.140:8080/1 mi/ es202_naics_annual.html. 